\title{
EFFECTS OF ELEVATION AND GENETIC INTROGRESSION ON GROWTH OF COLORADO RIVER CUTTHROAT TROUT
}

\author{
Mark C. Belk ${ }^{1,3}$, Michael N. McGee ${ }^{1,2}$, and Dennis K. Shiozawa ${ }^{1}$
}

\begin{abstract}
Inland populations of cutthroat trout have suffered dramatic declines and some subspecies are considered threatened or endangered. Understanding patterns of variation and factors that influence life history in populations is important for conservation and management. We determined effects of elevation, sex, and genetic introgression (with Yellowstone cutthroat trout, Oncorhynchus clarkii lewisi, and rainbow trout, Oncorhynchus mykiss) on growth rates of Colorado River cutthroat trout (Oncorhynchus clarkii pleuriticus) in the Sheep Creek drainage in the Uinta Mountains of Utah. In this high-elevation system, native trout grew slowly and matured relatively late. Elevation, sex, and genetic introgression all had significant effects on growth rates. Growth rates were lower at higher elevations. Males were slightly larger than females, and cutthroat trout in locations that were more introgressed grew faster than those at nonintrogressed locations. Both abiotic effects and effects of introduced salmonids must be addressed in long-term management programs to ensure the sustainability of native trout populations.
\end{abstract}

Key words: life history, growth rate, elevation, genetic introgression, otolith, inland cutthroat trout.

Colorado River cutthroat trout (Oncorhynchus clarkii pleuriticus) are native to the Colorado River Basin above the Grand Canyon. Their range has been dramatically reduced since the settling of the western United States (Behnke 1992, Young 1996, Young et al. 2005). This subspecies is now limited to headwater streams in a few drainages in Utah, Colorado, and Wyoming. Population declines have resulted from habitat degradation, water development, and introduction of other species and subspecies of trout. In headwater streams, where most of the remaining populations are located, introduction of Yellowstone cutthroat trout (Oncorhynchus clarkii bouvieri), brown trout (Salmo trutta), brook trout (Salvelinus fontinalis), and rainbow trout (Oncorhynchus mykiss) has led to competitive displacement of native Colorado River cutthroat trout and hybridization of this species with Yellowstone cutthroat trout and rainbow trout (Behnke 1992, Duff 1996, Dunham et al. 2002).

Currently, Colorado River cutthroat trout exist primarily in small, isolated populations (Hepworth et al. 2001, Young 2008). Such isolated populations can be adapted to their local environment on a small geographic scale (Hutchings 1993). In addition to population variation caused by local adaptation, differences in growth rate and life history among populations of cutthroat trout may be related to variation in physical factors. Catchment orientation, catchment discharge, and available habitat can have significant effects on growth and life history (Gresswell et al. 1997, Isaak and Hubert 2004). Habitat factors such as water chemistry, primary production, cover, water temperature, and residual pool depth during periods of low flow may affect time of spawning, growth rate, and mortality (Kennedy et al. 2003). Although interest in native cutthroat trout has increased in recent years, life history patterns and phenotypic variation is poorly known for most populations of Colorado River cutthroat trout (Young 2008). Observational data documenting effects of the physical environment and introduced species are important for determining conservation priorities and management actions (Dunham et al. 2002, Peterson et al. 2004).

Remnant populations of pure Colorado River cutthroat trout exist in several isolated headwater streams of the Sheep Creek drainage in northeastern Utah. Rainbow trout (RT) and Yellowstone cutthroat trout (YCT) have been stocked into this system for many years, resulting in genetic introgression of some populations (Bray 1999, Jones 1999). Our objectives were to characterize the life history of high-elevation populations of Colorado River cutthroat

\footnotetext{
${ }^{1}$ Department of Biology, Brigham Young University, Provo, UT 84602.

${ }^{2}$ Present address: c/o BLM Marsing Field Office, 20 First Ave. West, Marsing, ID 83639.

${ }^{3}$ E-mail: mark_belk@byu.edu
} 


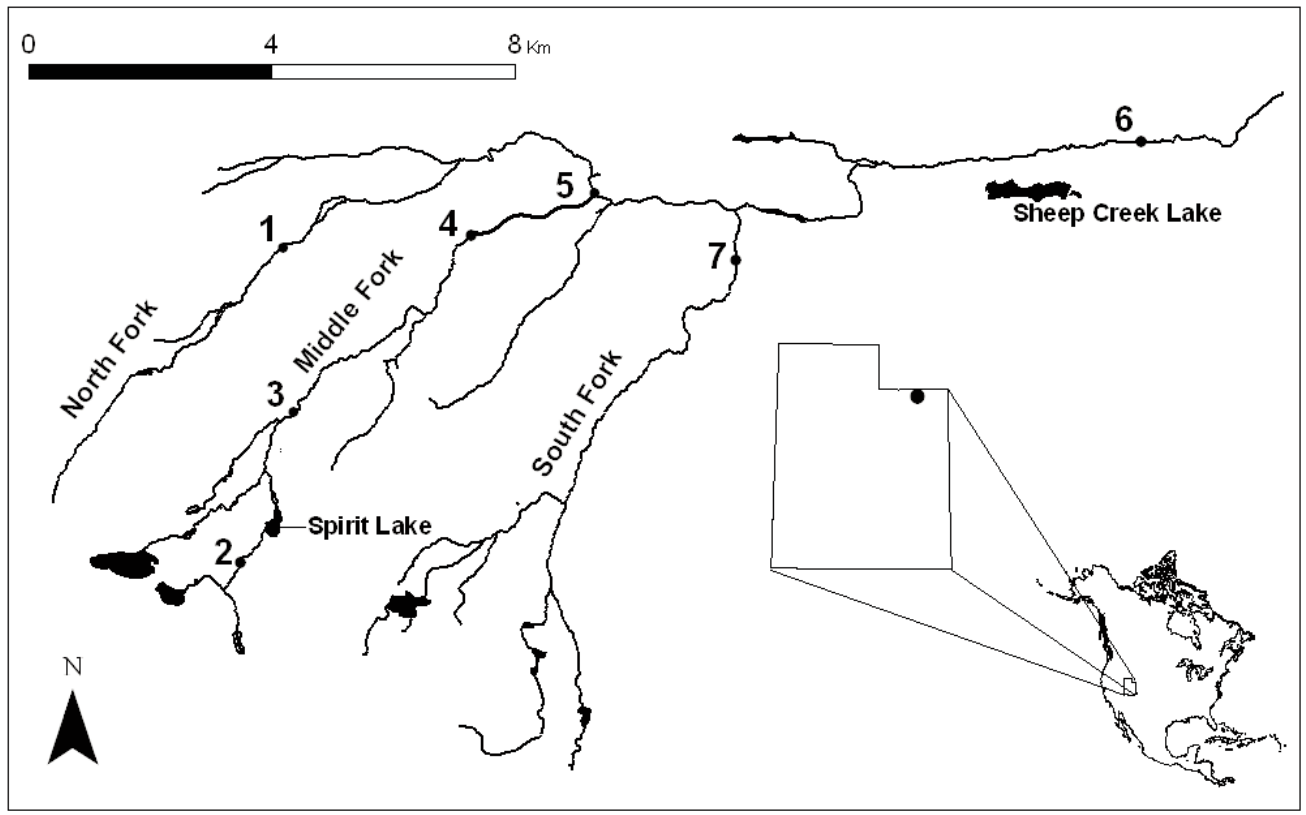

Fig. 1. Map of collection sites of Colorado River cutthroat trout in the Sheep Creek drainage, Utah. Collection sites were identified as follows: North Fork (site 1), Middle Fork above Spirit Lake (site 2), Middle Fork below Spirit Lake (site 3), Middle Fork (site 4), Hickerson Park (site 5), Sheep Creek below Sheep Creek Lake (site 6), and South Fork (site $7)$.

trout in the Sheep Creek drainage and to determine the relative effects of elevation, sex, and genetic introgression on somatic growth patterns.

\section{Methods \\ Study Site}

The Sheep Creek drainage is located on the northeastern slope of the Uinta Mountains in Daggett County, Utah. The riparian habitat consists of coniferous forests, willows, and alpine meadows. Elevation of collection sites varied from $3200 \mathrm{~m}$ at the Middle Fork of Sheep Creek above Spirit Lake to $2475 \mathrm{~m}$ at the sampling site below Sheep Creek Lake.

We sampled 7 sites in the Sheep Creek drainage. Sites were chosen to represent spatially separated segments of the drainage along an elevation gradient. North Fork (site 1) and South Fork (site 7) were located on tributaries of the main stem and were characterized by relatively small stream size and shallow pools compared to the lower Middle Fork. The North Fork site was $>4 \mathrm{~km}$ from the confluence with the main stem, and the South Fork site was about $1 \mathrm{~km}$ from the main stem confluence.
Middle Fork above Spirit Lake (site 2) was the highest elevation site, and fish from this location were possibly able to occupy the lake habitat during low-water periods. Site 3Middle Fork below Spirit Lake-was separated from site 2 by Spirit Lake, and fish could not access the lake from downstream because of a drop at the lake outlet. Middle Fork (site 4) was downstream about $4 \mathrm{~km}$ from site 3 and upstream about $3 \mathrm{~km}$ from Hickerson Park (site 5). Sheep Creek below Sheep Creek Lake (site 6) was $>6 \mathrm{~km}$ below the nearest sampling site and well below the confluence of the 3 forks. Site 6 was located at the lowest elevation of all sites (Fig. 1).

\section{Collection and Measurement of Growth and Life History}

To characterize variation among locations, we collected 50 fish from each of the 7 sites during late May to mid-June 1995 using a backpack electroshocking unit. We measured mass and total length for each fish and removed the pair of sagittal otoliths. We also inspected gonads to determine sex and reproductive state. We collected 3 additional samples (about 25 fish each) from the South Fork 


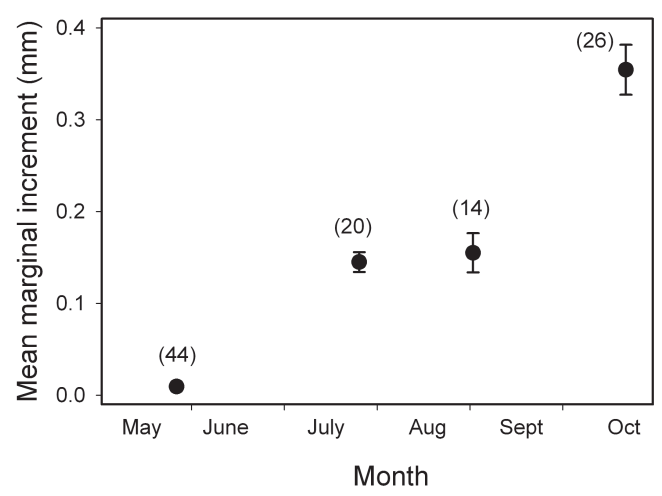

Fig. 2. Mean marginal increment of otoliths during the growing season of Colorado River cutthroat trout at the South Fork location in the Sheep Creek drainage of Utah. Numbers in parentheses represent sample sizes. Marginal increment increases during the growing season suggest formation of one annulus per year. Bars represent 2 standard errors above and below the mean.

location in July, September, and October for a marginal increment analysis in order to validate the assumption that rings on the otolith corresponded to true annuli (Brothers 1987). To test the assumption that only one presumptive annulus was formed per year, we plotted marginal increment width against month of collection.

To determine age and growth patterns, we processed otoliths as follows. We mounted otoliths, concave side down, on strips of plastic acetate. To make annuli visible, we removed material from the convex surface using 400 600 grit sandpaper on a lapidary grinding wheel (Struers, Dap-7 model). Annuli appeared as opaque bands when viewed against a dark background. We captured video images of each otolith (under 12X magnification) using a video camera mounted on a dissecting microscope and Sigma Scan image analysis software (Jandel Scientific 1993). Using the video images and direct observation, 2 researchers independently estimated the number of annuli of each otolith. We then compared independent estimations and resolved discrepancies by concurrent observation. Additionally, to determine growth rates, we measured total radius of each otolith along the longest axis and the radius at each annulus from video images. We used measures of total length and otolith radii to back-calculate total length-at-age for all previous ages for each fish using a modified FraserLee formula (Campana 1990). The pattern of marginal increment growth suggests formation of only one ring per year, validating the assumption that rings represent true annuli (Fig. 2). We were able to estimate age for 370 of the 412 fish collected for life history analysis.

Age at maturity was determined by comparing the proportion of reproductive individuals to nonreproductive individuals at each age. Reproductive females had enlarged ovaries with obvious ova. Males were considered reproductive if their testes were low in the abdomen and had a milky white color. Proportion of individuals that were reproductive was plotted against age, and age at maturity was defined as the age at which at least $50 \%$ of individuals were reproductive. We used both nuclear (Bray 1999) and mitochondrial (Jones 1999) markers to estimate the level of genetic introgression of populations. The average percent introgression was computed with a double weighting of the internal transcribed spacer (ITS) data since the ITS region is part of the nuclear genome. However several assumptions were made in this estimate. The first was that no assortative mating is taking place between Colorado River cutthroat trout, Yellowstone cutthroat trout, and rainbow trout. Second, we treated the ITS region as a simple diploid locus. Experimental crosses between cutthroat and rainbow trout (D.K. Shiozawa unpublished data) indicate that the ITS region in the F1 generation does not undergo concerted evolution, but the inheritance of the ITS region is not documented for backcrosses. For these reasons, and because the estimate is only a sample, the averages presented here should be considered as general estimates of the degree of introgression in each location. A more precise estimate would require multiple nuclear markers, which were not available at the time of the study. Introgression with RT ranged from $0 \%-47 \%$, and introgression with YCT ranged from 9.3\%21.3\% (Table 1) among locations.

\section{Statistical Analysis}

We were interested in the effects of elevation, sex, and genetic introgression on backcalculated total length at ages $1-4$ years. Rather than comparing size at each age independently, as in a typical univariate analysis, we were interested in the entire growth pattern from ages 1-4, so we used a repeated-measures design for the analysis. Total length was the response variable, and total lengths were 
TABLE 1. Elevation and percent introgression with rainbow trout (RT) and Yellowstone cutthroat trout (YCT) at 7 sampling locations for Colorado River cutthroat trout in the Sheep Creek drainage of Utah.

\begin{tabular}{|c|c|c|c|}
\hline \multirow[b]{2}{*}{ Location } & \multirow[b]{2}{*}{ Elevation $(\mathrm{m})$} & \multicolumn{2}{|c|}{ Percent introgression } \\
\hline & & RT & YCT \\
\hline 1. North Fork & 2774 & 0 & 14 \\
\hline 2. Middle Fork above Spirit Lake & 3030 & 6 & 21 \\
\hline 3. Middle Fork below Spirit Lake & 2853 & 15 & 19 \\
\hline 4. Middle Fork & 2719 & 6 & 21 \\
\hline 5. Hickerson Park & 2829 & 0 & 9 \\
\hline 6. Sheep Creek below Sheep Creek Lake & 2475 & 0 & 12 \\
\hline 7. South Fork & 3200 & 47 & 21 \\
\hline
\end{tabular}

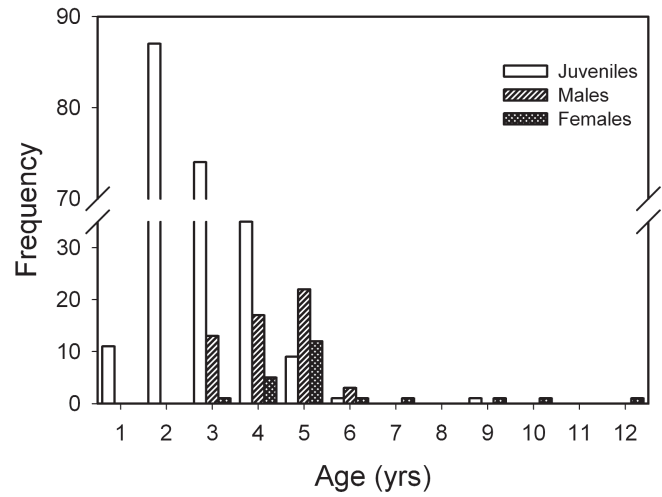

Fig. 3. Age frequency histogram of juvenile and reproductive (by sex) Colorado River cutthroat trout combined for all locations.j

TABLE 2. Results of a repeated-measures mixed-model analysis of covariance on effects of habitat, sex, introgression, and elevation on length at ages 1-4 of Colorado River cutthroat trout in the Sheep Creek drainage of Utah. Significant effects are indicated with bolded $P$-values.

\begin{tabular}{lccr}
\hline Effect & df & $F$ & $P$-value \\
\hline Year of age & 3,617 & 2920 & $<\mathbf{0 . 0 0 0 1}$ \\
Sex & 2,364 & 10.6 & $<\mathbf{0 . 0 0 0 1}$ \\
Year by Sex & 6,613 & 9.7 & $<\mathbf{0 . 0 0 0 1}$ \\
Introgression-RT & $1,8.15$ & 10.88 & $\mathbf{0 . 0 1 0 6}$ \\
Introgression-YCT & $1,7.04$ & 8.49 & $\mathbf{0 . 0 2 2 4}$ \\
Elevation & $1,7.2$ & 24.3 & $\mathbf{0 . 0 0 1 6}$ \\
\hline
\end{tabular}

available for up to 4 years for each individual. Thus, year of age was the repeated variable (each individual yielded up to 4 estimates of length -1 for each age). Because our sampling structure included random and fixed effects, we used a mixed model (PROC MIXED; SAS Institute, Inc. 1990, Littell et al. 1996). The model included 2 random variables: sampling location (sites 1-7) and individual (because up to 4 lengths at age were used from each indi- vidual). Random effects account for the variance-covariance structure among locations and individuals. Fixed effects in the model were (1) year of age (included as a main effect to account for repeated measures of growth over years for each individual) and (2) a combination variable of sex by age for which we had 3 categories-mature males, mature females, and undetermined juveniles. Three other variables, elevation and percent introgression of the population with RT and YCT, were continuous population-level variables and we included them as covariates.

\section{RESUlts}

Fish ranged from young-of-year to age 12 , but only 27 individuals (of the 370) were older than age 5 . Mean age was 3 years $(s=1.5$; Fig. 3 ), and the youngest mature individuals were age 3 for both sexes. Average age at maturity was age 4 for males and age 5 for females (Fig. 3). Average total length at maturity for males (age 4), adjusted for all effects in the model, was $169 \mathrm{~mm}\left(s_{\bar{x}}=2.4\right)$. For females, average total length at maturity (age 5), adjusted for all effects in the model, was $187 \mathrm{~mm}\left(s_{\bar{x}}=2.8\right)$.

Length-at-age and corresponding growth rates varied among locations (Fig. 4). Both main effects had a significant effect on lengthat-age and the interaction year-of-age by sex was significant. In addition the 3 covariates, elevation, and percent introgression with RT and YCT were significant (Table 2). All 3 sex/age groups were about the same size at age 1 , but by age 3 , prospective males and females were larger than undifferentiated juveniles, and males were larger than females (Fig. 5). Introgression with RT had a significant positive effect on growth rates, accounting for a maximum difference in length of about $13 \mathrm{~mm}$ across ages. Similarly, introgression with YCT had a 


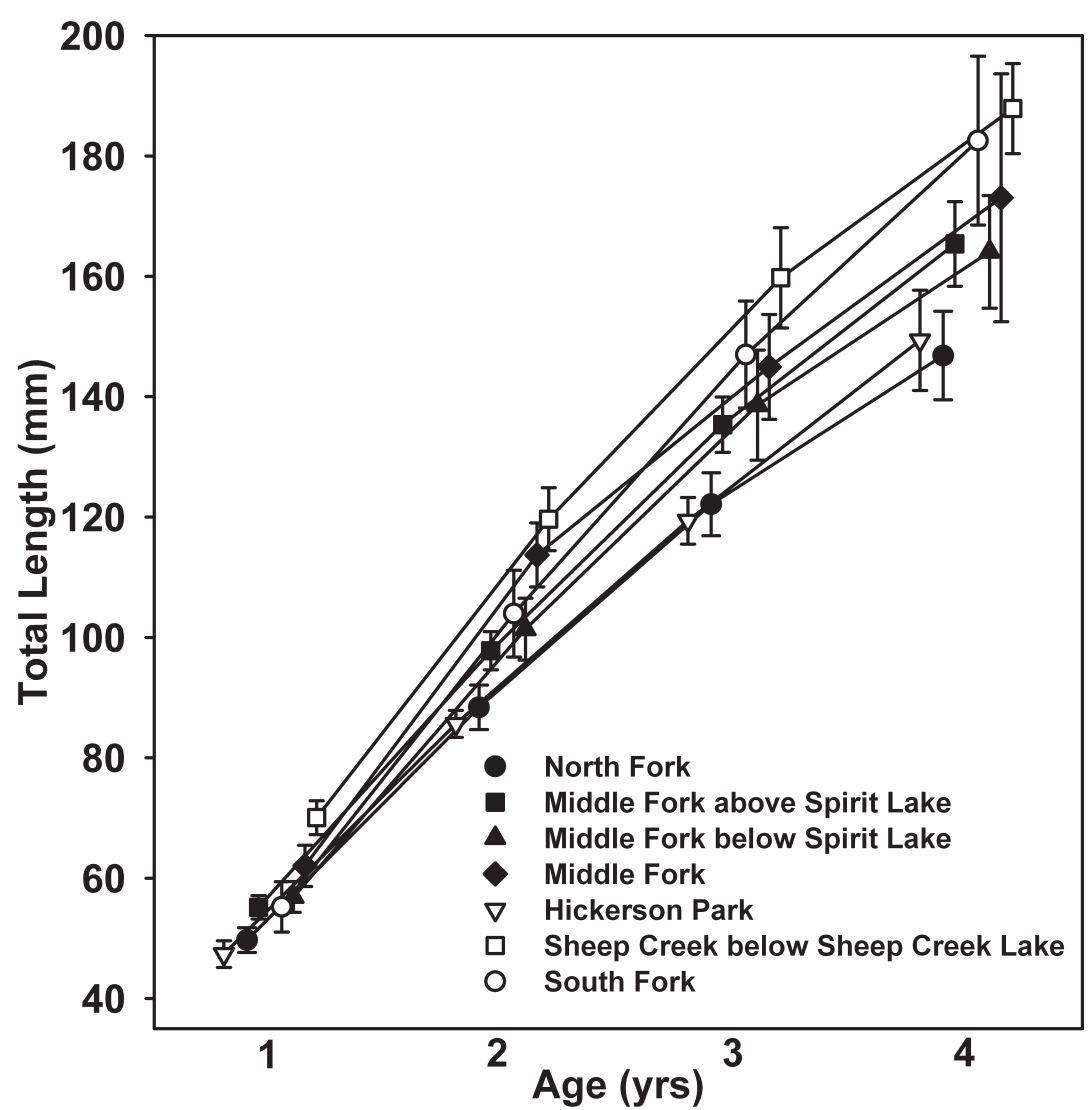

Fig. 4. Mean total length of Colorado River cutthroat trout at ages 1-4 by collection location. Bars represent 2 standard errors above and below the mean.

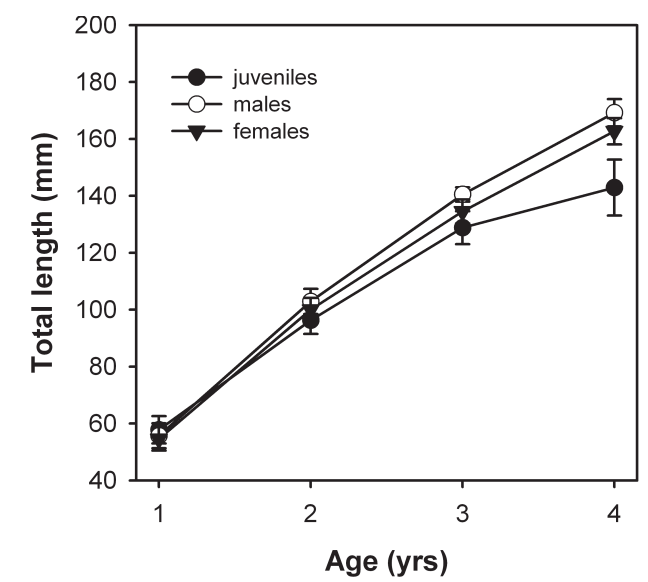

Fig. 5. Mean total length of Colorado River cutthroat trout at ages $1-4$ by sex and maturity category. Bars represent 2 standard errors above and below the mean. significant positive effect on growth rates, accounting for a maximum difference in length of about $18 \mathrm{~mm}$ across ages. Elevation had a significant negative effect on growth rates, accounting for a maximum difference in length of about $24 \mathrm{~mm}$ across ages.

\section{Discussion}

This study provides comparative data of the life history of Colorado River cutthroat trout at high elevations. Maximum life span appears to be about age 6 , with the exception of fish at the location associated with Spirit Lake. This result is consistent with age and growth patterns found in high-elevation populations of westslope cutthroat trout (O. c. lewisi; Downs et al. 1997) and the general expectation for western trout (Behnke 1992). Most of the fish age 6 and older in this study were collected from the site above Spirit Lake. These older 
ages are likely a result of the opportunity fish have to move into the lake during periods of low water and extreme seasonal temperature fluctuations in the stream (Adams et al. 2001).

Since most individuals do not reproduce until their 4th or 5th year, and few fish from the study sites live to their 6th year, most individuals that do live to reproduce will only reproduce once during their lifetime. It could be that reproduction has such high energy requirements that few individuals can reserve enough energy after spawning to overwinter (e.g., Gresswell et al. 1997). In other similar systems, female cutthroat trout may spawn in alternate years because of resource limitation (Willson 1997, Schmetterling 2001). This pattern of life history suggests that Colorado River cutthroat trout populations at these locations may be marginally viable (Harig and Fausch 2002). As such, heavy angling-caused mortality in the Sheep Creek system could be particularly detrimental to the persistence of selfsustaining populations of native trout.

Because of low growth rates of native fish in this system, size of stocked fish could negatively impact the native cutthroat trout population. Rainbow trout stocked into the system average 254 to $305 \mathrm{~mm}$ (based on captures during sampling) and are one year of age when stocked. Few cutthroat trout in the system ever reach that size. The larger rainbow trout may take the best feeding lanes and habitat (Fausch 1983). Large male rainbow trout and fastgrowing hybrids may have reproductive advantages that may augment introgression. Larger males in this system may have greater access to spawning females. In golden trout $(O . \mathrm{m}$. aguabonita), the largest males always occupied the position closest to the spawning female (Knapp and Vredenburg 1996). After accounting for all other sources of variation, we found that faster growth rates were exhibited at locations where native trout were introgressed with rainbow trout and Yellowstone cutthroat trout than at locations where native trout were genetically pure. Laboratory studies suggest that rainbow-cutthroat hybrids suffer some reduction in fitness (Leary et al. 1995, Allendorf et al. 2004). However, data from this study and others suggest that hybrids may have higher fitness-related performance (Seiler and Keeley 2007) or at least have no decline in fitness relative to genetically pure populations (Rubidge and Taylor 2004). Equivocal or advantageous performance of hybrids may lead to rapid introgression of populations and development of homogenized hybrid swarms, as observed in many cutthroat trout populations (Allendorf et al. 2001, Young 2008).

High elevations had a strong negative effect on growth. That result was consistent with observations in other species and systems (Kennedy et al. 2003, Young et al. 2005, Harvey et al. 2006). Elevation should be considered a broad surrogate for several environmental variables such as temperature, growing season length, stream size and depth, and height and coverage of riparian vegetation. From our data it is not clear how these variables interact to reduce growth rates. However, the site with the highest elevation was also the location associated with access to Spirit Lake. Even with access to the lake, growth rates were still among the lower of the 7 locations (Fig. 4). Thus stream size or depth may not be as important as temperature-related variables in determining somatic growth rates.

\section{ACKNOWLEDGMENTS}

We thank C. Jones, A. Bray, R.P. Evans, L. Hatfield, C. Crosby, K. Mullins, and S. Phillips for help with sampling. Funding was provided in part through the USDA Forest Service.

\section{Literature Cited}

Adams, S.B., C.A. Frissell, and B.E. Rieman. 2001. Geography of invasion in mountain streams: consequences of headwater lake fish introductions. Ecosystems 2001:296-307.

Allendorf, F.W., R.F. Leary, N.P. Hitt, K.L. Knudsen, L.L. LUNDQUIST, AND P. SPRUELL. 2004. Intercrosses and the U.S. Endangered Species Act: should hybridized populations be included as westslope cutthroat trout? Conservation Biology 18:1203-1213.

Allendorf, F.W., R.F. Leary, P. Spruell, and J.K. WenBURG. 2001. The problems with hybrids: setting conservation guidelines. Trends in Ecology and Evolution 16:613-620.

BeHnKe, R.J. 1992. Native trout of western North America. American Fisheries Society Monograph 6, American Fisheries Society, Bethesda, MD. 275 pp.

BraY, A. 1999. Nuclear genetic markers distinguishing between Colorado River cutthroat trout, Yellowstone cutthroat trout, and rainbow trout of the Sheep Creek drainage, Utah. Master's thesis, Brigham Young University, Provo, UT.

Brothers, E.B. 1987. Methodological approaches to the examination of otoliths in aging studies. Pages 319330 in R.C. Summerfelt and G.E. Hall, editors, The age and growth of fish. Iowa State University Press, Ames. 
Campana, S.E. 1990. How reliable are growth back-calculations based on otoliths? Canadian Journal of Fisheries and Aquatic Sciences 47:2219-2227.

Downs, C.C., R.G. White, and B.B. Shepard. 1997. Age at sexual maturity, sex ratio, fecundity, and longevity of isolated headwater populations of westslope cutthroat trout. North American Journal of Fisheries Management 17:85-92.

DuFF, D.A. 1996. Conservation assessment for inland cutthroat trout. USDA Forest Service, Intermountain Region, Ogden, UT.

Dunham, J.B., S.B. Adams, R.E. Schroeter, and D.C. NovingER. 2002. Alien invasions in aquatic ecosystems: toward an understanding of brook trout invasions and potential impacts on inland cutthroat trout in western North America. Reviews in Fish Biology and Fisheries 12:373-391.

FAusch, K.D. 1983. Profitable stream positions for salmonids: relating specific growth to net energy gain. Canadian Journal of Zoology 62:441-451.

Gresswell, R.E., W.J. Liss, G.L. Larson, and P.J. BARTLEIn. 1997. Influence of basin-scale physical variables on life history characteristics of cutthroat trout in Yellowstone Lake. North American Journal of Fisheries Management 17:1046-1064.

Harig, A.L., and K.D. Fausch. 2002. Minimum habitat requirements for establishing translocated cutthroat trout populations. Ecological Applications 12:535-551.

Harvey, B.C., R.J. Nakamoto, and J.L. White. 2006. Reduced streamflow lowers dry-season growth of rainbow trout in a small stream. Transactions of the American Fisheries Society 135:998-1005.

Hepworth, D.K., M.J. Ottenbacher, and C.B. ChamBERLAIN. 2001. Occurrence of native Colorado River cutthroat trout (Oncorhynchus clarki pleuriticus) in the Escalante River drainage, Utah. Western North American Naturalist 61:129-138.

Hutchings, J.A. 1993. Adaptive life histories affected by age-specific survival and growth rate. Ecology 74:673-684.

IsAaK, D.J., AND W.A. HuberT. 2004. Nonlinear response of trout abundance to summer stream temperatures across a thermally diverse montane landscape. Transactions of the American Fisheries Society 133: 1254-1259.

JANDEL SCIENTIFIC. 1993. Mocha image analysis software: user's manual. Version 1. Jandel Scientific, San Rafael, CA.

Jones, C.P. 1999. Genetic variation within native and nonnative (Oncorhynchus) populations of the Sheep Creek drainage, Utah. Master's thesis, Brigham Young University, Provo, UT.

Kennedy, B.M., D.P. Peterson, and K.D. Fausch. 2003. Different life histories of brook trout populations invading mid-elevation and high-elevation cutthroat trout streams in Colorado. Western North American Naturalist 63:215-223.

Knapp, R.A., And V.T. VRedenburg. 1996. Spawning by golden trout-characteristics of spawning fish, seasonal and daily timing, redd characteristics, and microhabitat preferences. Transactions of the American Fisheries Society 125:519-531.

Leary, R.F., F.W. Allendorf, and G.K. Sage. 1995. Hybridization and introgression between introduced and native fish. American Fisheries Society Symposium 15:91-101.

Littell, R.C., G.A. Milliken, W.W. Stroup, and R.D. WOLFINGER. 1996. SAS system for mixed models. SAS Institute, Inc., Cary, NC.

Peterson, D.P., K.D. Fausch, and G.C. White. 2004. Population ecology of an invasion: effects of brook trout on native cutthroat trout. Ecological Applications 14:754-772.

Rubidge, E.M., and E.B. Taylor. 2004. Hybrid zone structure and the potential role of selection in hybridizing populations of native westslope cutthroat trout (Oncorhynchus clarki lewisi) and introduced rainbow trout (O. mykiss). Molecular Ecology 13: 3735-3749.

SAS InSTITUTE, INC. 1990. SAS user's guide: statistics. Version 6. SAS Institute, Inc., Cary, NC.

Schmetterling, D.A. 2001. Seasonal movements of fluvial westslope cutthroat trout in the Blackfoot River drainage, Montana. North American Journal of Fisheries Management 21:507-520.

SeILeR, S.M., AND E.R. KeELey. 2007. Morphological and swimming stamina differences between Yellowstone cutthroat trout (Oncorhynchus clarkia bouvieri), rainbow trout (Oncorhynchus mykiss), and their hybrids. Canadian Journal of Fisheries and Aquatic Sciences 64:127-135.

WiLLSON, M.F. 1997. Variation in salmonid life histories: patterns and perspectives. USDA Forest Service Research Paper PNW-RP-498.

YounG, M.K. 1996. Summer movements and habitat use by Colorado River cutthroat trout in small, montane streams. Canadian Journal of Fisheries and Aquatic Sciences 53:1403-1408.

2008. Colorado River cutthroat trout: a technical conservation assessment. General Technical Report RMSR-GTR-207-WWW, USDA Forest Service, Rocky Mountain Station, Fort Collins, CO. 123 pp.

Young, M.K., P.M. Guenther-Gloss, And A.D. Ficke. 2005. Predicting cutthroat trout (Oncorhynchus clarkii) abundance in high-elevation streams: revisiting a model of translocation success. Canadian Journal of Fisheries and Aquatic Sciences 62:2399-2408.

Received 17 January 2008 Accepted 14 August 2008 